\title{
Instinto de clase y resistencias obreras en Asturias bajo la dictadura franquista*
}

\author{
Rubén Vega García**
}

Resumen: En las condiciones extremas que impone la dictadura franquista, la herencia del movimiento obrero pervivirá de modo soterrado, expresada en formas de resistencia que descansan sobre solidaridades primarias que requieren muy escasa o ninguna organización, giran en torno a propósitos concretos ampliamente compartidos y entrañan un riesgo limitado por adoptar - en apariencia - formas no políticas. Pese a su carácter casi instintivo, los sujetos colectivos y los medios sociales en que se manifiestan remiten a la persistencia de una memoria del movimiento obrero que subsiste tras la derrota de la guerra civil. Las mujeres asumen el peso de las formas de solidaridad basadas en los lazos familiares o los vínculos comunitarios, en tanto que los hombres protagonizan las centradas en el ámbito laboral. Estas actitudes colectivas remiten a códigos de conducta y valores compartidos, hasta el punto de que en no pocas ocasiones se hacen efectivas a través de formas de comunicación no verbal y pueden prescindir no sólo de la letra escrita sino incluso de la palabra. Sobre estas prácticas de solidaridad y resistencia se asienta, no obstante, la actividad de los exiguos grupos organizados que desarrollan una militancia activa contra la dictadura y de algunas de esas solidaridades primarias obtienen recursos -tanto materiales como moralesindispensables para proseguir su lucha.

Palabras clave: clandestinidad; instinto y conciencia de clase; resistencia antifranquista; movimiento obrero.

Resumo: Nas condições extremas que a ditadura franquista impõe, a herança do movimento operário sobreviverá de modo soterrado, expressando-se em formas de resistência que descansam sobre solidariedades primárias que requerem escassa ou nenhuma organização, giram em torno de propósitos concretos amplamente compartilhados e entranham um risco limitado por adotar - nas aparências formas não-políticas. Apesar de seu caráter quase instintivo, os sujeitos coletivos e os meios sociais nos quais se manifestam remetem à persistência de uma memória

* El presente texto es una versión revisada y ampliada que tiene su origen en otro presentado en el Coloquio Les conflits dans les mondes ibériques et ibéro-américains contemporains. Des élaborations sociales et politiques aux constructions symboliques, celebrado en la Université Paris-Sorbonne del 17 al 19 de noviembre de 2011.

** Universidad de Oviedo. 
do movimento operário que subsiste depois da derrota da guerra civil. As mulheres assumem o peso das formas de solidariedade embasadas em laços familiares ou em vínculos comunitários, enquanto os homens protagonizam aquelas centradas no âmbito de trabalho. Estas atitudes coletivas remetem a códigos de conduta e valores compartilhados, até que, em não poucas ocasiões, tornam-se efetivas através de formas de comunicação não verbal. Sobre estas práticas de solidariedade e resistência se assenta, no entanto, a atividade dos exíguos grupos organizados que desenvolvem uma militância ativa contra a ditadura e de algumas dessas solidariedades primárias obtêm recursos - tanto materiais como morais indispensáveis para prosseguir sua luta.

Palavras-chave: clandestinidade; instinto e consciência de classe; resistência antifranquista; movimento operário.

Nosotros, preparación política no teníamos nada: eso hay que reconocerlo. Nosotros obrábamos por conciencia de clase, instinto de clase. ${ }^{1}$

Asturias ofrece en el primer tercio del siglo XX una configuración sociopolítica marcada por la fuerte implantación de las organizaciones obreras, que llegan a ser, en los años treinta, hegemónicas desde el punto de vista político y cultural. La derrota sufrida en la guerra civil supone un corte drástico y bañado en sangre (unas 7.000 víctimas mortales de la represión franquista en una región de 850.000 habitantes) y la instauración de una dictadura que emplea denodados esfuerzos para borrar todo vestigio de ese pasado. Pese a todo, esta herencia pervivirá de modo soterrado, expresada en formas de resistencia que descansan sobre solidaridades primarias que requieren muy escasa o ninguna organización, giran en torno a propósitos concretos ampliamente compartidos y entrañan un riesgo limitado por su carácter en apariencia no político. Las mujeres asumen el peso de las formas de solidaridad basadas en los lazos familiares o los vínculos comunitarios, en tanto que los hombres protagonizan las centradas en el ámbito laboral. Estas resistencias y ayudas remiten a códigos de conducta y valores compartidos, hasta el punto de que en no pocas ocasiones se hacen efectivas a través de formas de comunicación no verbal. Sobre estas prácticas de solidaridad y resistencia se asienta, no obstante, la actividad de los exiguos grupos organizados que desarrollan una militancia activa contra la dictadura y de algunas de esas solidaridades primarias obtienen recursos - tanto materiales como morales - indispensables para proseguir su lucha. ${ }^{2}$

1 Casimiro Bayón, militante comunista y miembro de la comisión obrera de Mina La Camocha en 1957 (Langreo, 16-VI-1997). Archivo personal del autor.

2 La opción de englobar a una parte de estas actitudes de resistencia bajo el término "instinto de clase" ha suscitado dudas entre los lectores del borrador del presente texto. Es empleado aquí para designar respuestas que, contradiciendo al poder e ideología dominantes, pertenecen más al terreno de las mentalidades que de la conciencia y que no alcanzan, por tanto, una expresión en términos ideológicos sino que remiten a vínculos de solidaridad y sociabilidad propios de la clase obrera y expresan de forma intuitiva, más que discursiva, sus intereses y antagonismos. El concepto, que aparece empleado - aunque no definido - en diversas obras de Lenin, ha sido retomado, con cierto mecanicismo, por el estructuralismo althusseriano y también, en buena medida subvertido, por Bourdieu. Adoptamos aquí la siguiente definición: "En la base existe el instinto de clase, las formas espontáneas (no organizadas ni teorizadas) de resistencia a la explotación y a sus consecuencias, la opresión política y la dominación ideológica. También podría decirse: en la base existen siempre formas espontáneas de la conciencia de clase" tomada de LEVICES MALLO, Jesús J. “Reproducción y resistencia”. In: REYES, Román (dir.) Diccionario Crítico de 
La clase obrera asturiana había sido, hasta finales del siglo XIX, cuantitativamente poco numerosa y apenas organizada. Durante el primer tercio del siglo XX, sin embargo, la potencia movilizadora y la implantación del movimiento obrero convierten a Asturias en un referente en toda España. En las zonas mineras e industriales, dos generaciones de trabajadores se socializan imbuidas de los valores, códigos y lealtades propios del movimiento obrero, en cualquiera de sus tendencias ideológicas y organizativas (socialistas, anarcosindicalistas y comunistas). La cultura obrera se forja en un clima de intensa conflictividad social y se asienta sobre una vasta red de locales sindicales, asociaciones, ateneos, bibliotecas circulantes... que constituyen tanto espacios de sociabilidad como de afirmación de valores e identidades. Pero, desde 1937, la dictadura franquista ilegaliza todas las organizaciones de clase, incauta sus bienes y desata sobre sus militantes una durísima represión, incluida la eliminación física de dirigentes y cuadros medios, cortando de raíz toda muestra visible de la tradición obrerista que había arraigado a lo largo de las cuatro décadas precedentes. En estas condiciones, la pervivencia de una memoria del movimiento obrero y la continuidad de comportamientos e identidades clasistas han de expresarse bajo formas apenas explícitas, basadas en códigos y valores ampliamente compartidos y que, precisamente por ello, apenas requieren organización.

\section{Pervivencia y transmisión de la conciencia obrera}

La existencia previa de organizaciones de clase sólidamente implantadas y con una militancia numerosa hace que los efectos de la represión alcancen, en mayor o menor medida, a la mayoría de las familias de trabajadores, entre las cuales el ambiente es de desafección respecto al régimen impuesto por los vencedores. Impera una percepción que puede ser viva o difusa pero, en todo caso, generalizada de pertenecer a los perdedores y estar siendo tratados como vencidos en una contienda que muchos habían interpretado en términos de guerra de clases. El precio por ser "rojo" o simplemente contar en la familia con personas que se hayan significado como tales ("paseados" o ejecutados, presos, huidos, exiliados) resulta muy elevado y, en tiempos de hambre y escasez, endurece hasta el extremo las condiciones en que se desenvuelve la vida de muchos. Una mera acusación sin fundamento, originada por rencores personales o cuestiones ajenas a la política, puede tener consecuencias irreparables. ${ }^{3}$

La socialización del miedo como parte de la vida cotidiana genera respuestas específicas, tanto de carácter solidario como de prevención frente a posibles delatores y confidentes. ${ }^{4}$ En torno a las puertas de las cárceles se van tejiendo lazos entre las mujeres que acuden a llevar alimentos a sus padres, maridos 0 hermanos presos, siempre con el temor de que en la noche anterior hayan sido ejecutados. Del mismo modo, en el interior de las prisiones, los reclusos se agrupan

Ciencias Sociales, THEORIA | Proyecto Crítico de Ciencias Sociales - Universidad Complutense de Madrid.

3 Sirvan de muestra, entre muchos posibles, dos testimonios recogidos por el autor en entrevistas recientes: Adelina Antuña relata cómo fue víctima de torturas tras haber rechazado mantener relaciones sexuales con un miembro de la Guardia Civil que al verse desairado la señala como sospechosa de colaborar con la guerrilla (Gijón, 18-X-2011). Amor Pardo recuerda las humillaciones sufridas en la escuela y en la iglesia por ella y sus hermanos a causa de la ideología comunista de su padre (Tornón-Villaviciosa, 4-VIII-2011).

4 Acerca del miedo profundamente instalado en lo cotidiano, SÁNCHEZ MOSQUERA, Marcial. Del miedo genético a la protesta. Memoria de los disidentes del franquismo. Sevilla: Fundación de Estudios Sindicales, 2008. 
rápidamente en función de su pertenencia a un determinado partido o sindicato y muy pronto crearán "comunas" mediante las cuales ponen en común los escasos recursos (alimentos, sobre todo) que sus familiares son capaces de hacerles llegar.

En estas condiciones, en las que pocos se sienten a salvo, nunca faltan los casos de quienes están dispuestos a colaborar con los represores, bien sea para obtener beneficio personal o para salvarse a sí mismos. La consciencia de que a su alrededor existen no sólo falangistas que desde su condición de vencedores ejercen funciones de control y represión sino también vecinos, compañeros de trabajo e incluso antiguos camaradas convertidos en delatores obliga a extremar las cautelas. Entre los mecanismos de defensa más eficaces se cuenta el aislamiento social de estas personas, procurando su estigmatización como traidores. ${ }^{5}$ Tanto el trabajo en minas y fábricas como la vida en los barrios obreros facilitan un ambiente que penaliza duramente estas conductas. La presión puede llegar a ser insostenible para aquellos que son catalogados de confidentes policiales, viéndose obligados incluso a emigrar. Esta es la única alternativa que se abre para quienes delatan a compañeros de militancia clandestina, donde rigen códigos de gran dureza al respecto, pero a menudo también es el destino de los que traicionan a compañeros de trabajo o incluso de quien se ha mostrado desleal con un vecino respetado y estimado. ${ }^{6}$ El carácter oprobioso que esta conducta tenía a los ojos de la mayoría otorga a las organizaciones antifranquistas un medio para contrarrestar el daño que causa en sus filas la infiltración o la debilidad. A este respecto, las emisiones de radio que el PCE mantiene a través de Radio España Independiente (más conocida como La Pirenaica) pueden alcanzar una extraordinaria eficacia: la denuncia de un confidente a través de las ondas provocaba efectos fulminantes si se trataba de un trabajador. Pero incluso los funcionarios de prisiones pueden ser sensibles a esta presión ante el riesgo de ser denunciados públicamente y algunos testimonios dan cuenta de policías temerosos de ser señalados a través de las ondas. ${ }^{7}$

La herencia del movimiento obrero de preguerra incluye también actitudes de rechazo hacia quienes rompen la unidad en situaciones de conflicto. Los esquiroles han de hacer frente al desprecio de sus compañeros y vecinos de tal modo que verses señalado como tal sirve de aviso para otros que puedan tener la tentación de imitar su conducta. Una especie de código de honor que rinde respeto a quienes secundan una huelga y menosprecia a aquellos que la rompen parece instalado en el ambiente. El por entonces joven minero Ignacio Peón rememora

5 Juan José Díaz recuerda cómo en el barrio gijonés donde crece, dos mujeres eran señaladas como delatoras. Una de ellas, conocida como "la civila", es objeto de la inquina de los vecinos (Gijón, 16-IV-1997).

6 El militante comunista Manuel Terente, considerado responsable de una cadena de detenciones en 1952, ha de abandonar su trabajo en Mina La Camocha y cambiar de residencia, según relata Gerardo Lorda (Gijón, 24-XII-1994). Bibiano Durán, uno de los mineros deportados a raíz de las huelgas de 1962, es identificado por sus compañeros de destierro como confidente y ha de optar por irse a Bélgica, según los también deportados Vicente Gutiérrez Solís (Langreo 2001) y Constantino Alonso (Mieres, 2001), ambas entrevistas pertenecientes a la Serie Huelgas de 1962 del Archivo de Fuentes Orales para la Historia Social de Asturias (en adelante, AFOHSA). En 1962, durante los meses que José Argüelles permanece encarcelado, su puesto como cartero es ocupado por un vecino que es a su vez un comerciante, pero la mayoría del pueblo reacciona con un boicot que le forzará a cerrar la tienda y emigrar a Madrid (Entrevista a José Argüelles, AFOHSA, Serie Huelgas de 1962).

7 A fines de los años 50, Manuel García Valle desenmascara a un minero del pozo Modesta, el cual decide abandonar el trabajo. Unos años más tarde, estando en prisión, el propio Manuel da cuenta del éxito de las gestiones de una comisión de presos al sugerir al director de la cárcel que los nombres de algunos funcionarios podrían ser denunciados a través de la Pirenaica (MUÑIZ SÁNCHEZ, Jorge. A mi hay que matarme de frente, Oviedo: Fundación Juan Muñiz Zapico/KRK, 2011, p. 72 y 97-98). A su vez, Eduardo Rincón relata cómo, durante el período en que estuvo siendo torturado en 1961, uno de los policías, tras haber aliviado su tormento, le pidió que su nombre no apareciera en las emisiones de la Pirenaica (RINCÓN GARCÍA, Eduardo. Cuando los pasos se alejan. Santander: La Bahía, 2011, p. 146). 
su descubrimiento de estas claves en el contexto de un paro en protesta por un accidente laboral en los años cincuenta. Aunque la mina se pobló de guardias civiles y el miedo estaba presente, su aprendizaje se orienta en otra dirección y descubre nuevos códigos y significados:

yo no conocía la palabra de esquirol, pero después, [algunos] trabajaron allí y eran unos esquiroles y [yo] iba enterándome de que no trabajar era lo correcto y que trabajar era ser esquirol. Explicómelo un poco mi padre. ${ }^{8}$

Los códigos que el movimiento obrero ha conseguido arraigar entre los trabajadores permanecen vigentes a pesar del clima represivo y operan con notable fuerza a la hora de premiar o penalizar las conductas mostradas en situaciones de conflicto. Quienes encabezan las reivindicaciones reciben una recompensa moral en términos de respeto social, en tanto que aquellos que rompen la solidaridad son objeto de desprecio. Cuando la conflictividad emerge con fuerza, estos valores compartidos por la mayoría se convierten para los agentes de la dictadura en un problema político de difícil neutralización. Así lo percibe claramente el Jefe Superior de Policía al hacer balance de la situación creada en las cuencas mineras tras las huelgas de la primavera de 1962:

... se viene manifestando una gran división en los centros de trabajo, al señalar como 'enemigos' de la clase trabajadora a los muy pocos que no apoyaron la huelga o que se reintegraron antes al trabajo y ya, incluso, a los que políticamente se consideran afectos al Régimen y es aquí donde se perciben entremezclados los matices económicos, sociales y políticos. Hacen patente la fuerza de la unión al creer que las libertades concedidas lo fueron por su coacción y así, estos detenidos aparecen como los 'más dignos' ante los trabajadores y, poco menos que se les rinde pleitesía, y se abomina de los que los consideran traidores a la clase obrera (...), y éstos, amedrentados, no reaccionan y se convierten en masa o encuentran dificultades para desenvolver normalmente su vida en aquellos medios. ${ }^{9}$

También otras formas de colaboración con la dictadura, incluso si no entrañan daño para terceros, son motivo de desprestigio a los ojos de compañeros y vecinos. Así sucede con quienes deciden participar en las estructuras del sindicalismo oficial impuesto por los vencedores con vistas a la neutralización de los conflictos de clase. Concebido como una extensión de los aparatos del Estado e integrando en una estructura común a trabajadores y empresarios, el Sindicato Vertical permanece sumido en el descrédito entre una mayoría de trabajadores en aquellos sectores que cuentan con tradición de movimiento obrero y donde pervive una memoria latente de las organizaciones sindicales de clase. Durante mucho tiempo, entre los mineros la desafección se expresó mediante el boicot a

8 Entrevista a Ignacio Peón Fonfría, AFOHSA, serie Movimiento Obrero. En el mismo sentido, el profesor de Literatura Benigno Delmiro, proveniente de una familia de mineros, relata cómo en una ocasión en la que expresó dudas acerca de una convocatoria de huelga en la Enseñanza, su madre, que nunca sostuvo militancia política alguna, le dijo de forma tajante: “en esta familia, en cien años, nunca hubo un esquirol”.

9 Informe del Jefe Superior de Policía sobre las medidas a adoptar en la huelga de agosto, Oviedo, 22 de agosto de 1962. Reproducido íntegro en VEGA, Rubén (Coord.) Las huelgas de 1962 en Asturias. Gijón: Trea/ Fundación Juan Muñiz Zapico, 2002, p. 539-540. 
las elecciones sindicales, absteniéndose o votando a candidatos inexistentes (Sofía Loren, Di Stéfano, una mula, un compañero considerado idiota...) para mostrar el desprecio por ese cauce de representación. Este clima llegará a convertirse en un problema para los militantes de oposición que, a partir de los años 50, adoptan una táctica de infiltración en los sindicatos verticales. Particularmente para los comunistas, justificar esa opción frente al rechazo frontal que propugnan socialistas y anarcosindicalistas requiere un esfuerzo de explicación que resulta laborioso dentro de sus propias filas y plantea ante el resto de trabajadores la necesidad de diferenciarse de los franquistas llevada al extremo. Diversos testimonios concuerdan en detalles como la costumbre de acudir a las reuniones con un bocadillo para evitar consumir la comida que se les ofrecía, para de este modo no verse "contaminados" por la aceptación de cualquier cosa que provenga del Régimen. Conscientes de que, para muchos trabajadores, la colaboración con los sindicatos verticales es fuente de desprestigio, su condición de opositores que actúan desde dentro debe quedar patente incluso en los gestos aparentemente intrascendentes:

Ellos te daban de comer, cuando ibas ahí... Mira, del pozu Lláscares, los que íbamos ahí íbamos controlados y llevábamos el bocadillo para comer. Incluso nos amenazaron con que nos podían expulsar por negarnos a comer en el Sindicato [...]. Porque la gente, en el fondo, creía que por aquella comida ya te ibas a vender. Tenías que sostener eso, aunque fuera un poco torcido [...]. Como había tanto conformismo y la empresa te facilitaba eso... el Sindicato... para que no te movieras. ${ }^{10}$

Así mismo, dentro de una lógica de clase, la idea de que tanto las empresas como sus directivos y personal de confianza son antagonistas en quienes no cabe confiar está presente incluso allí donde no se aprecia actividad de militantes antifranquistas. Sobre estos ejes girará buena parte de las actitudes que dan cuenta de la persistencia de una conciencia obrera soterrada pero activa. En los centros de trabajo, aún sin presencia organizada de opositores, reina a menudo un ambiente que claramente diferencia el "ellos" (la dirección, los mandos y las autoridades) del "nosotros" (los obreros). Hidroeléctrica del Cantábrico podría ser un buen ejemplo de esto: hasta bien entrados los años 60 no se encuentra organización alguna ni muestras visibles de oposición pero sí se detecta un sentimiento de solidaridad, cierto orgullo de clase y un instinto de oponerse a lo que diga la dirección. Con el tiempo, pese a tratarse de una empresa donde no se producen conflictos abiertos (ninguna huelga tiene lugar durante la dictadura) y en la que reina una actitud paternalista, los trabajadores darán pruebas de cohesión: tras haber boicoteado las elecciones sindicales de 1963, en 1966 el funcionamiento de una comisión obrera propicia que se decida en asamblea participar. Cuando la dirección de la empresa responde promoviendo otra candidatura, la plantilla reacciona de modo unánime y se abstiene, provocando la nulidad de la votación, que ha de ser repetida y permite elegir en la segunda convocatoria su candidatura íntegra y sin oposición. ${ }^{11}$

La cohesión de los trabajadores constituye la principal protección a la que pueden acogerse quienes encabezan las reivindicaciones o se implican en actividades clandestinas. Únicamente la unidad del grupo puede reducir el riesgo al

10 Historia de vida de Manuel García Valle, AFOHSA.

11 Entrevista a Juan José Díaz (Gijón, 16-IV-1997). 
que se exponen. Esta cohesión está basada tanto en una cultura de clase compartida que es en buena medida herencia de los tiempos de pujanza del movimiento obrero previos a la derrota en la guerra civil como en la similitud de las condiciones materiales en que viven y trabajan. Las redes y espacios de sociabilidad trabados en torno a los espacios de residencia y lugares de trabajo actúan como refuerzo de las conductas solidarias. Los barrios obreros, las identidades profesionales, los vínculos y afinidades relacionados con el trabajo son ingredientes decisivos. El efecto de refuerzo de las solidaridades y el caldo de cultivo para la acción colectiva que representan las barriadas obreras no escapa a la observación policial ni tampoco a la de las organizaciones opositoras. Un informe relativo a las huelgas de 1962 constata, desde la óptica represiva, la dificultad de control que representan núcleos de población particularmente homogéneos en cuanto a sus habitantes, "fáciles para un intercambio de ideas, impresiones y consignas" y donde los motivos de descontento se ven amplificados por la presencia de personas con antecedentes políticos desfavorables, ya fueran anteriores o posteriores a la guerra. ${ }^{12}$ En el mismo sentido se expresa un análisis referido a la huelga del año siguiente a cargo de un sindicato ilegal de origen cristiano:

Hasta cierto punto, el agrupamiento profesional se da por barriadas, un poco (salvando las naturales distancias de tiempo) al estilo de la Edad Media: barrios de pescadores, de mineros, de metalúrgicos, campesinos, etc. Muchas veces, trabajadores laboralmente dispersos - trabajan en distintos lugares y pozos -, pero profesionalmente unificados - todos dependen de la misma actividad económica -, viven urbanamente acumulados. Estos barrios actúan como de cajas de resonancia de noticias, opiniones, rumores, etc. favoreciendo con ello la propagación de los conflictos. ${ }^{13}$

Ante la dificultad para expresar las ideas políticas de forma abierta, los gestos y los aspectos simbólicos adquieren una significación reforzada. La conmemoración de determinadas fechas como el $1^{\circ}$ de Mayo puede ser expresada a través la indumentaria, vistiendo alguna prenda de color rojo o llevando un clavel del mismo color en la solapa. La proclamación de la República podía ser reivindicada mediante la colocación en lugares visibles y de difícil acceso de banderas tricolores. ${ }^{14}$ Otras veces, la voz popular encuentra formas indirectas de subvertir el orden impuesto negándose a asumir los nombres oficiales. En Gijón, la plaza del Generalísimo será conocida como plaza del parchís, en alusión a su forma cuadrangular que recordaba un tablero de ese juego. En La Felguera, la barriada del grupo de viviendas Francisco Franco fue pertinazmente denominada "el gochu" (cerdo, en lengua asturiana). ${ }^{15}$

El contexto represivo impuesto por la dictadura condiciona notablemente la transmisión intergeneracional de una memoria obrera. A menudo, quienes han

12 Informe del Delegado Gubernativo para Gijón, 27-VI-62, AHP-SGC.

13 Informe de la Federación Sindical de Trabajadores (FST) sobre la huelga minera de 1963, 10-X-1963, reproducido en Centro de Documentación y de Estudios, Boletín Informativo, n 19, París, noviembre 1963.

14 Jesús González relata cómo cada $1^{\circ}$ de Mayo se concentraba gente en Sama de Langreo con claveles, pañuelos, camisas u otras prendas de color rojo. Juanita Prieto recuerda una discusión mantenida con un policía que le recrimina ir vestida de rojo. AFOHSA, serie Movimiento Obrero. El abogado Manuel López recuerda en sus memorias un juicio en el que actuaba como defensor de varios procesados asturianos a quienes el juez obligó a quitarse las corbatas y pañuelos rojos. LÓPEZ, Manolo. Mañana a las once en la Plaza de la Cebada. Albacete: Bomarzo, 2011, p. 597-598.

15 TOMÉ, Sergio. "Cien barriadas de posguerra, hoy (Asturias y León)”. Boletín de la Asociación de Geógrafos Españoles, $n^{\circ}$ 52, 2010. 
sufrido la dureza de los tiempos de la guerra e inmediata postguerra mantienen actitudes de extrema cautela, lo que incluye una permanente reserva a la hora de rememorar el pasado. Con frecuencia, los testimonios coinciden en subrayar que en el ámbito doméstico rara vez se hablaba de cuestiones políticas y a menudo los jóvenes descubren de forma tardía la existencia de antecedentes de militancia o de víctimas de la represión en su propia familia. Pese a ello, no pocos jóvenes se situarán de forma casi instintiva en el campo del antifranquismo como fruto de sus vivencias infantiles dentro de familias represaliadas. La ausencia de relatos y discursos explícitos por parte de los mayores no impide tampoco la transmisión de un testimonio basado en la conducta que deja huella en los más jóvenes. ${ }^{16}$

La herencia del movimiento obrero y, con más dificultad, las adscripciones ideológicas y lealtades organizativas se materializan a menudo a través del ejemplo, a veces callado, de los veteranos. El futuro dirigente socialista Antón Saavedra da sus primeros pasos en organizaciones juveniles y culturales (Juventud Norteña y Amigos del Nalón) donde los comunistas llevan la iniciativa y atribuye su afiliación socialista al recuerdo de su abuelo, "aunque en casa no se hablara de ello". El abuelo, José Cantera, había sido concejal en 1931 y formado parte de la Ejecutiva del Sindicato Minero. Tras haber participado en la revolución de octubre de 1934 y en la guerra, fue condenado a muerte y conmutado y acabó muriendo en la mina en $1949 .{ }^{17}$

Otro futuro dirigente sindical socialista, en este caso sin actividad militante durante la dictadura, proporciona un relato acerca de su participación, con apenas 15 años de edad, en la huelga de la primavera de 1962 que ilustra la forma silenciosa en que se extiende el paro y la importancia que para los jóvenes adquiere la autoridad de los compañeros más veteranos, además del carácter en cierto modo iniciático que cobra su participación en acciones que entrañan riesgo pero otorgan al tiempo recompensa moral:

\footnotetext{
Me acuerdo como si fuera ahora mismo. Llegué [al trabajo] y aquel día la gente no hablaba. Estábamos en la grada [del astillero] y yo no sentía ruido [de las máquinas]. Y no se hablaba. $\mathrm{O}$ a lo mejor hablaban de la mar. Pero de lo que estaba pasando, nada. Y yo, como era el más guaje [en asturiano: niño], dije: - ¿Porqué no trabajamos?

- Estamos en huelga ¿no ves que lleven los mineros no sé cuánto tiempo en huelga?

- Y qué vamos a hacer.

- Nada, de momento todos quietos. Seguro que mandan acá a la guardia civil.

Hacia las 12 vamos al taller de calderería todos y había una pila de guardias civiles y uno se subió a los bancos de trabajo y dijo: ustedes se van todos a casa ahora mismo y después van a recibir una misiva y ia cumplirla! Y así fue: creo recordar que mandaron 30 cartas para pasar por comisaría y allí les dijeron que o empezábamos a trabajar o [los deportaban y] a uno lo mandaban a Burgos, a otro a nosedonde... - ¿Y qué vais a hacer?

- No, no, yo no trabajo. Yo, cuando entren a trabajar todos entro yo. Hay guardia civil controlando en la calle y en las empresas. Nosotros, como éramos chavales jóvenes, no conocíamos el peligro. Bajábamos
}

16 Segundo G. Magdalena recuerda la reacción de su padre -un minero sin militancia política- cuando siendo un niño llegó a casa con el uniforme del Frente de Juventudes (la organización juvenil del Régimen). Sin mediar explicación, le dio una bofetada y le dijo: "mañana mismo devuelves eso". Segundo González Magdalena (Oviedo, 22-III-1993).

17 Entrevista publicada en Atlántica XXII, nº 15, julio 2011, p. 25. 
e íbamos a vernos con la gente del [barrio del] Natahoyo. De nosotros nadie sospechaba nada. Éramos los que nos encargábamos de transmitir coses que nos decían ellos. Aquellos 406 que nos movimos más éramos los más jóvenes, los guajes. La verdad es que fue emocionante. Nunca habíamos visto una huelga. Y te sentías válido porque te decían: hay que ir a tal bar y allí van a estar fulano y fulano. Luego vas comprendiendo que era gente que estaba integrada en células del PCE fundamentalmente y ya se movía en aquella época.

Para nosotros era todo una novedad impresionante. Primero, aquello de la huelga, que es que no hablaban ni entre ellos para decirse buenos días. Aquello era el mundo del silencio. Yo estaba un poco asustado porque no lo entendía hasta que dijo aquel paisano que estábamos en huelga y que había que esperar. Este hombre no estaba en ninguna organización, pero sí lo entendía. No era un activista. Era un paisano que veía que no había más que sinrazón y entonces paraba con todas las consecuencias. Había otros dos que ya eran mayores, de 50 años o más, y eran líderes para todo. Eran líderes para trabajar, eran líderes para hablar. Uno era del [taller de] ajuste y otro de calderería. Luego, cuando ya se fue pudiendo hablar, sin que llegara la democracia todavía, supe que uno era socialista y el otro anarquista, que había estado afiliado a la CNT de joven. ${ }^{18}$

Las nuevas generaciones han de realizar, en cualquier caso, una reelaboración de dicha herencia, que se traduce en una adscripción a los principios de solidaridad, igualitarismo y rebeldía ante la injusticia y la confianza en respuestas basadas en la acción colectiva, que forman parte de un sustrato compartido por el movimiento obrero en su conjunto. ${ }^{19}$ Las continuidades se revelan en la mayor intensidad de las prácticas solidarias en los espacios donde el movimiento obrero ha sido hegemónico social y culturalmente en el pasado. En Asturias es posible contrastar, a este respecto, las zonas de tradición obrera - Gijón y las cuencas mineras - con una comarca de reciente industrialización como Avilés, donde no se constatan mecanismos que acrediten una cohesión de similar intensidad, ni tampoco formas eficaces de aislamiento de confidentes y colaboradores de la represión, a pesar de que éstos son numerosos, dado que la plantilla la empresa estatal siderúrgica que domina la vida de la ciudad ha sido configurada de este modo como estrategia consciente de control.

\section{Huelgan las palabras: códigos compartidos}

En Asturias, los conflictos laborales reaparecen con relativo retraso en relación con otras zonas industriales como el País Vasco o Cataluña. Hasta 1957 no

18 Entrevista a José Manuel Menéndez Rozada (Gijón, 1-VII-2011) AFOHSA, Serie Culturas del Trabajo.

19 La cuestión de la transmisión de la memoria del movimiento obrero ha sido abordada en los últimos años con cierta frecuencia: PÉREZ, José Antonio. "Continuidades y rupturas del obrerismo socialista de la Margen Izquierda vizcaína bajo el franquismo, 1937-1962”. V Encuentro de Investigadores del Franquismo, Albacete: Fundación $1^{\circ}$ de Mayo/Universidad de Castilla La Mancha, 2003 y “El PCE y la reconstrucción del obrerismo militante en la margen izquierda del Nervión (1947-1962)”. In: BUENO, Manuel, HINOJOSA, José y GARCÍA, Carmen (Coords.) Historia del PCE. I Congreso 1920-1977, Madrid: FIM, 2007. TÉBAR HURTADO, Javier. "Contraindicacions de la 'política de la victoria'. Notes sobre repressió i identitat de la militància obrera dels anys seixanta”, en PAGÉS i BLANCH, Pelai (dir.) Franquisme i repressió. La repressió franquista als Països Catalans (1939-1975). Valencia: Universidad de Valencia, 2004. BORDERÍAS, Cristina, BORREL, Mónica, IBARZ, Jordi y VILLAR, Conchi, “Los eslabones perdidos del sindicalismo democrático: la militancia femenina en las CCOO de Catalunya durante el Franquismo". Historia Contemporánea, n² 26, Bilbao, 2003. VEGA GARCÍA, Rubén. "Entre la derrota y la renovación generacional. Continuidad y ruptura en la protesta social”. In: MATEOS, Abdón (Ed.) La España de los cincuenta. Madrid: Eneida, 2008. 
se produce una huelga de grandes dimensiones. A partir de esa fecha, sin embargo, la conflictividad será frecuente e intensa, particularmente en la minería. La huelga sigue constituyendo un delito de rebelión militar juzgado conforme al Código de Justicia Militar hasta entrados los años sesenta. Incluso posteriormente, las medidas represivas desplegadas entrañan una gran dureza, comportando riesgo de despidos, torturas y cárcel para quienes encabezan la protesta obrera. Frente a esto, la mayoría de los mineros y una parte de los metalúrgicos adoptan formas de generar y extender los conflictos que no requieren discursos ni propaganda escrita, dos medios de provocar la huelga que constituyen delito y conducen de inmediato a sus autores a una comisaría o un cuartel. Frente a esto, un mecanismo instintivo de protección articula las acciones colectivas de modo que sus impulsores no resulten fácilmente identificables. Sin palabras, mediante gestos y sobreentendidos que todos comparten, un pozo minero puede paralizar su actividad en un movimiento de toda su plantilla al unísono que, sin embargo y en contra de las apariencias, revela la existencia de fuertes liderazgos. Unos pocos trabajadores, revestidos de prestigio entre sus compañeros por sus virtudes personales y profesionales, son capaces de catalizar el ambiente general y conducir a centenares de mineros a la huelga sin mediar ningún Ilamamiento explícito. El sistema más habitual consiste en romper la rutina diaria de los movimientos que preceden a la entrada al trabajo. En los vestuarios, cuando todos coinciden, provocar una situación anómala al no realizar el cambio de la ropa de calle por la de faena desencadena un cruce generalizado de miradas que va sembrando la inquietud en todo el grupo hasta paralizarlo. En ese momento, los más involucrados emprenden el abandono del recinto sin entrar a trabajar y son seguidos por el resto. El procedimiento consigue con notable eficacia proteger de la represión a los líderes y se basa en la indispensable cohesión del grupo, que hace que la mayoría que no estaba previamente advertida reaccione sin embargo como un solo hombre secundando a los pocos que han desencadenado la acción.

En la minería, esta acción colectiva y silenciosa, en apariencia espontánea pero que encierra una preparación previa y encubre liderazgos firmes y respetados, suele concretarse en un gesto: no bajar la percha donde las ropas de trabajo de los mineros permanecen colgadas a varios metros de altura para procurar su ventilación. Quienes no bajan la percha en el momento en que todos se disponen a iniciar su jornada expresan de modo inequívoco, con su presencia pasiva, la intención de no trabajar ese día y, con su simple mirada, lanzan a sus compañeros el reto de desafiar a los líderes y romper la unidad. Permanecer dentro del grupo y respetar sus códigos de acción colectiva suele representar una fuerza superior al temor a una represión cuyos riesgos, de todos modos, se minimizan con este procedimiento.

Cuandolos conflictossegeneranenelinterior delamina, laspalabras sevuelven necesarias pero el propio medio en que se desenvuelven propicia el anonimato y facilita en control. Están a resguardo de miradas ajenas, la comunicación se produce entre compañeros que trabajan en estrecho contacto y cualquier delación puede ser duramente penalizada. La entrada y salida del pozo ha de producirse necesariamente por un único conducto, de modo que basta con bloquear ese acceso. Para ello pueden bastar unos pocos que se muestren más decididos que el resto. Las primeras huelgas del sector, en 1957 y 1958, son provocadas mediante el encierro de todo un relevo en el interior del pozo: centenares de trabajadores 
que a la hora de concluir su jornada son interceptados por algunos compañeros. ${ }^{20}$ Permanecer a cientos de metros de profundidad representa un refugio seguro frente al despliegue policial que se produce en el exterior. En otras ocasiones, el desencadenante es la mano anónima que corta la presión del aire comprimido que alimenta los martillos neumáticos de los picadores. En el momento en que estos quedan en silencio, la paralización se extiende por el interior, los mineros se encaminan a la salida y la reparación de la avería no puede ya restablecer la normalidad. Todos han comprendido que no se trata de un accidente sino de una llamada a la paralización del trabajo.

En no pocas ocasiones, la extensión de los paros a partir de un foco inicial tiene como desencadenante un eficaz sustitutivo de la propaganda escrita. La posesión y distribución de octavillas está tipificada como un delito de propaganda ilegal y puede conducir a la cárcel. Su confección resulta laboriosa y arriesgada y no siempre está disponible en el momento preciso. Durante los años 50 las organizaciones clandestinas, muy debilitadas por la represión, apenas disponen de medios para elaborar y de personas para distribuir la propaganda, que normalmente llega desde el exilio por complicados conductos. En los 60, cuando se generalizan los conflictos, el problema consiste a veces en procurar inmediatez a las respuestas a situaciones concretas, de modo que la propaganda llega con retraso respecto a la necesidad planteada en un momento determinado. El vacío se cubre con la "siembra" de maíz en lugares estratégicamente elegidos (vestuarios, puertas de acceso, caminos, medios de transporte) trasladando de este modo un mensaje que apela a la solidaridad con otros compañeros que ya están en huelga y acusa de cobardía a quienes no les secundan. De este modo consiguen, por ejemplo, parar toda una factoría de varios miles de trabajadores como la de Duro Felguera "un grupo de mujeres que sembraron de maíz la entrada principal de la Fábrica y soltaron una docena de gallinas vestidas con bragas". ${ }^{21} \mathrm{EI}$ maíz es, en Asturias, alimento de gallinas y éstas sinónimo de falta de hombría, una acusación que representa una afrenta en medios laborales tan exclusivamente masculinos como la minería o la metalurgia. Aunque su distribución se realiza también a escondidas -generalmente de noche y evitando la vigilancia policial y de los guardas jurados- ni la compra ni el reparto de maíz constituye delito y permite igualmente hacer llegar un mensaje inequívoco. Este recurso no es en absoluto incompatible con la propaganda escrita sino que a menudo se combinan ambos lenguajes, retroalimentándose mutuamente. Los argumentos que faltan en el maíz - pura apelación a la virilidad- se encuentran en las octavillas. ${ }^{22}$

Con estas formas de actuación, parcas en palabras, basadas en el instinto y la cohesión, no es infrecuente que los conflictos se desaten sin que hayan sido

20 Testimonio de Avelino Pérez, Serie Disertaciones, AFOHSA. GARCÍA, Manuel “Otones”. Lucha y libertad. Oviedo: Fundación Juan Muñiz Zapico/Fundación Horacio Fernández Inguanzo, 2002, p. 45.

21 BAYÓN GARCÍA, Víctor. Crónica de una lucha. Mi actividad en el Partido Comunista de España. León: 2011, p. 61.

22 La huelga de la primavera de 1962 se generaliza en Gijón el 17 de mayo tras haber amanecido los accesos a las grandes empresas metalúrgicas sembrados de maíz. El trabajador siderúrgico y futuro dirigente anarcosindicalista Eduardo Prieto rememora el impacto que este hecho causó y la forma escalonada en que se fue produciendo el paro: "Ios que ya teníamos cierta conciencia nos dimos cuenta de que nos estaban llamando gallinas. A las 8 de la mañana paró el taller de ajuste, luego paró calderería y a las 12 había parado toda la fábrica" (testimonio contenido en el documental Hay una luz en Asturias... testigos de las huelgas de 1962, Fundación Juan Muñiz Zapico, 2002). El uso del maíz como forma de extender las huelgas no era privativo de Asturias ni del sector minero. Hemos podido constatar su operatividad en la minería leonesa o entre los metalúrgicos vizcaínos en diversas entrevistas: Benjamín Rubio (Villablino) y Nicolás Redondo. Sobre la extensión de esta práctica a Barcelona durante las huelgas de 1962, DOMĖNECH, Xavier. Clase obrera, antifranquismo y cambio político. Madrid: Catarata, 2008, p. 29-31. 
previamente planteadas las reivindicaciones, de modo que la empresa ha de buscar las causas a través de enlaces del sindicalismo oficial que a menudo carecen de las claves de lo sucedido. Una vez más, la minería constituye el sector donde más vigorosamente se expresa esa resistencia, que neutraliza la propaganda franquista y desautoriza a sus instrumentos sindicales de control. Así lo constata un informe de 1963:

En las minas las cosas son diferentes. Los mineros, especialmente los de fondo, que constituyen la base de todas las huelgas, empiezan por acudir a la boca del pozo con 15, 20 y hasta 30 minutos de anticipación. Se explica: durante las siete horas de jornada que dura el encierro no pueden fumar ni un simple cigarrillo por razones de seguridad. Viene, pues, de antiguo, el hacer un poco de tertulia antes de iniciar la tarea. De hecho son reuniones donde se comenta todo lo habido y por haber y donde tienen eco todas las quejas y disgustos obreros. Cuando el ambiente está cargado, de estas concentraciones suelen partir las chispas que acaban prendiendo fuego a todo el ambiente. No hace falta una organización previa, ni un plan preconcebido, ni instigación del extranjero ni agentes subversivos. Puede ser suficiente una provocación patronal o estatal. Si las cosas estuvieran tan bien organizadas y premeditadas como sugiere la propaganda oficial en estos casos, no tendrían sentido las carreras y sofocos que se han dado algunos enlaces sindicales presentando escritos y demandas para justificar paros ya producidos. Los representantes obreros han pretendido en todo caso formalizar la situación y dar al conflicto cierto estado de legalidad aún dentro del carácter ilegal que tiene la huelga en España, y, en la medida de lo posible, amortiguar los golpes de la represión. ${ }^{23}$

A menudo, las palabras ni siquiera son necesarias en condiciones de estricta clandestinidad. Salvo breves coyunturas en las que se relaja la presión represiva, las asambleas son un hecho muy infrecuente hasta bien avanzados los años $60 \mathrm{y}$, dado el riesgo que entrañan, no constituyen un escenario para el debate sino para revalidar liderazgos. El mero hecho de haber reunido valor para hablar ante los compañeros acredita la condición de portavoz y selecciona a los más decididos. Durante largo tiempo, el resurgir del movimiento obrero ha de retrotraerse a formas pre-sindicales como la creación de comisiones de trabajadores que plantean peticiones o negocian en nombre de sus compañeros, constatando la escasa operatividad de los sindicatos clandestinos en un contexto tan represivo. Como veremos más adelante, estas primitivas comisiones no suelen emanar de una elección formal sino de un mecanismo de selección natural que hace que sean los más decididos y respetados quienes las integran. Muchas otras expresiones de solidaridad se asientan igualmente sobre vínculos comunitarios, de vecindad, compañerismo o identidad, requiriendo muy escasa o nula organización. Se trata de formas primarias y hasta cierto punto instintivas de resistencia ante condiciones extremadamente adversas, respuestas "naturales" en el concreto ecosistema social constituido por comunidades obreras depositarias de la herencia de preguerra, reprimida pero latente. ${ }^{24}$

Cuando la represión se abate sobre militantes de organizaciones clandestinas,

23 Informe de FST sobre la huelga minera de 1963, 10-X-1963.

24 Acerca de la persistencia de la memoria en comunidades obreras, con especial referencia a los mineros, FENTRESS, James y WICKHAM, Chris. Social Memory. Oxford: Basil Blackwell, 1992 Traducción español: Memoria social, Madrid: Cátedra, 2003, p. 142-156. 
junto a la ayuda material que suelen recibir, el aliento moral mediante gestos de apoyo tácito encuentra múltiples formas de expresarse. Algunos mineros que tras ser despedidos han de ganarse la vida como agentes de seguros se convierten en vendedores de un elevado número de pólizas que no responde tanto a sus dotes comerciales como a su condición de represaliados. ${ }^{25}$ Presos políticos salidos de prisión que al ir a pagar su consumición en un bar se encuentran con que han sido invitados por un desconocido reciben de este modo muestras de aprobación. ${ }^{26}$ El mismo significado adquiere para algunas víctimas de torturas recibir multitud de visitas que sirven tanto para constatar el maltrato que han sufrido como para arroparles a ellos y a su familia en momentos tan difíciles. ${ }^{27}$

La muerte, como situación rodeada de rituales fuertemente arraigados y difícilmente perseguibles, ofrece diversas posibilidades de expresión de solidaridades e incluso de movilización y protestas. Especial intensidad tienen estas manifestaciones en medios sociales ligados a la minería, dado que la particular relación de los mineros con la muerte ha dado lugar a una cultura específica que rodea de gran solemnidad tanto los funerales como los accidentes mortales. Así se constata en algunos entierros cuyo carácter multitudinario está directamente vinculado a la significación política de los fallecidos y también en la pugna largamente sostenida en torno a la respuesta dada a los accidentes mortales en la mina.

En 1965, el entierro de la conocida luchadora antifranquista Constantina Pérez se convierte en un acto de masas a pesar del vasto despliegue policial. Su nombre - junto al de Anita Sirgo - había resonado dentro y fuera del país tras haber sido objeto de torturas y un corte de pelo durante la huelga minera de 1963, hecho denunciado en un manifiesto de un centenar de intelectuales. Al morir, dos años más tarde, la concentración de gente para rendirle tributo de despedida adquiere un significado político inequívoco. El carácter no religioso del entierro, por expreso deseo de la fallecida, refuerza el desafío. Conforme a una interpretación que, a su pesar, también comparten las autoridades, la crónica del órgano del PCE, teñida de tintes épicos, describe el cortejo fúnebre como un acto de afirmación antifranquista:

El acompañamiento del cadáver de Tina al cementerio civil de Sama
de Langreo ha constituido además de una inmensa manifestación de
duelo del pueblo asturiano, una impresionante movilización contra la
dictadura.
La concurrencia fue algo grandioso; algo "nunca visto" decían
veteranos luchadores, viejos mineros. No es posible calcular el número
de personas que formaban racimos humanos en las plazas de la barriada
de La Juécara y de los apiñados en los dos kilómetros que separan la
casa de Tina del cementerio, a pesar de la lluvia torrencial que caía en
aquellos momentos.
Cuando el ataúd, sostenido por cuatro trabajadores, apareció en el
portal, cubierto de flores rojas yuna paloma de la paz en la parte superior
la emoción era inenarrable. Miles de hombres y mujeres lloraban
silenciosamente. No todos los que acudieron pudieron marchar por las

25 Así sucede, una vez despedidos de la mina, con el comunista Alfonso Braña, según relata su esposa Anita Sirgo (Oviedo, 20-III-2001) y el también comunista y líder de Comisiones Obreras Martín Fraga, de acuerdo con el testimonio de su esposa Eufrasia Alves (Gijón, 16-IV-2012).

26 Entrevista a Manuel Álvarez Ferrera (Gijón, 16-X-1995). En el mismo sentido, Francisco Prado Alberdi recuerda cómo, tras haber cumplido condena por su militancia política y sufrir frecuentes despidos a causa de su actividad sindical, era sistemáticamente invitado en los bares que frecuentaba.

27 Historia de vida de Manuel García Valle, AFOHSA. 
calles engrosando la manifestación y tenían que limitarse a seguir con la vista el cortejo.

Otro dato muy expresivo de cómo Asturias ha rendido homenaje a Tina es el agotamiento aquellos días de las flores en Sama de Langreo y en Mieres. ${ }^{28}$

Una situación similar se produce en Mieres a la muerte de otro conocido militante, cuya aureola se veía reforzada por largos años de cárcel y una minusvalía física que no había mermado su actividad:

El día 30 de enero ha muerto en Mieres el camarada Sacramento Gutiérrez. Los 20 años de cárcel y las torturas recibidas habían debilitado mucho su salud. El camarada "Mento" ha sido un militante comunista ejemplar, que ha dedicado plenamente su vida al Partido. Las mazmorras del Puerto de Santa María, Burgos y El Dueso jamás doblegaron su entereza de combatiente de primera fila. Después de salir de la cárcel en 1960, muy débil de salud, en ocasiones sin fuerza para respirar, el camarada Mento ha sido un incansable defensor de la causa de la clase obrera y de sus ideales comunistas. En su silla de ruedas motorizada, enviada por los asturianos residentes en Bruselas, recorría los lugares de Mieres animando continuamente a los trabajadores a combatir por la libertad y la democracia, explicando la política de nuestro Partido. De cuatro a cinco mil personas iban en el entierro civil de Mento. A la salida del barrio de San Pedro apareció la Policía dispuesta a perturbar su último descanso. El jefe de la policía local, Arce, y medio centenar de grises cortaron el paso a la comitiva y ordenaron meter el féretro en una carroza llamada por ellos a fin de impedir que los obreros siguieran llevándolo a hombros. La muchedumbre empezó a gritar a pleno pulmón: ¡ASESINOS! ¡COBARDES! ¡FASCISTAS! ¡LIBERTAD! ¡DEMOCRACIA!.29

Incluso en plena transición a la democracia, el cortejo que despidió al sindicalista Juan Muñiz Zapico se convirtió en una muestra de la capacidad de convocatoria de las organizaciones en que militaba (CC.OO. y PCE)y, por extensión, del conjunto de la izquierda. Del mismo modo, los socialistas habían despedido algún tiempo antes a Agustín González. Fuera de las cuencas mineras, Gijón había asistido en 1969 a un acto de características similares cuando un nutrido cortejo fúnebre acompañó al cadáver de Mario Diego Capote, un preso político muerto en la cárcel de Segovia por falta de atención médica. Los testimonios orales confirman, muchos años después, el impacto causado por estos y otros entierros y corroboran su papel como manifestación de un sentir político. ${ }^{30}$ La posibilidad de convertir los entierros en cauce para hacer visible la disidencia no se limita a la despedida de militantes conocidos como los anteriores. En general, los funerales crean un contexto en el que cualquier forma de represión se vuelve especialmente repudiable y, por lo tanto, ofrecen cierta ampliación de oportunidades como la aprovechada por los mineros despedidos que, mediados los años sesenta, se hacían presentes mediante una corona fúnebre con una leyenda que escuetamente despedía al compañero o vecino difunto en nombre de "los despedidos". ${ }^{31}$

28 Mundo Obrero, segunda quincena de octubre de 1965.

29 Mundo Obrero, 20-II-1969.

30 Historias de vida de Jesús González, Maruja Martínez Campa y Luís Nora, AFOHSA.

31 Así lo recuerda Severino Arias, uno de los portavoces de aquella Comisión de Despedidos, en entrevista publicada en La Nueva España, 7-VIII-2012. 
Una vez atribuida una significación inequívoca a estas muestras de duelo con ocasión de la muerte de militantes conocidos, la práctica puede ser subvertida para mostrar el sentimiento contrario, expresando la desafección hacia el muerto. Así sucede en algunos pozos mineros con motivo de la muerte del dictador. Ignacio Peón rememora cómo, al día siguiente de la muerte de Franco, mientras sus partidarios -habitualmente esquiroles en las huelgas- paraban en señal de dolor y homenaje, los mineros de su pozo entraron normalmente al trabajo para demostrar que no lamentaban su muerte. ${ }^{32}$

En las cuencas mineras, la siniestralidad laboral ofrece otro motivo poderoso para la expresión sorda de solidaridades fraguadas en torno a la especial relación que su trabajo guarda con la muerte. Un observador privilegiado, por su trabajo en el Departamento de Psicología Industrial de la empresa pública minera HUNOSA, lo describe en los siguientes términos: "contemplando un entierro minero da la sensación de que aquello es una manifestación silenciosa de protesta y rebeldía ante un destino común en el que se encuentran atrapados". ${ }^{33}$ La frecuencia de los accidentes mortales en el trabajo y la propensión de los mineros a atribuir las causas a las deficientes medidas de seguridad, adjudicando por tanto la responsabilidad a empresarios y autoridades, convierte cualquier funeral de trabajadores muertos en un acto de solidaridad y de reivindicación a un tiempo. De este modo, no sólo los entierros de significados militantes antifranquistas sino el de cualquier minero puede ejercer un efecto cohesionador y adquirir un sentido reivindicativo:

El intierro (sic) fue una azmiración (sic). Sus compañeros le regalaron una corona de claveles rojos, que parecía indicar la idea por la que él se dio la muerte. Pienso estos días ir a hacer una visita a la viuda, no es que la conozca mucho, porque me queda un poco lejos. Yo tengo todavía algo de dinero y creo que si ella lo necesita está en primer lugar, aunque sería doloroso que se olvidaran de ella y de sus tres hijos. ${ }^{34}$

Late, en estas circunstancias, una expresión del conflicto de clase, rayano a veces en el odio, y una muestra del orgullo profesional y la cultura propia de los mineros. ${ }^{35}$ Bajo la dictadura franquista, la dimensión política de estas situaciones se acrecienta debido a la prohibición que pesa sobre la respuesta habitual, consistente en paralizar el trabajo en señal de duelo y asistir masivamente al entierro. Inicialmente, las condiciones no permiten un desafío abierto y dan lugar a formas de resistencia pasiva como el bajo rendimiento:

Cuando las autoridades franquistas dieron la orden de que en caso de asistencia de los mineros a los entierros de sus compañeros, suprimirían a los obreros una parte del jornal, los puntos, primas y demás una ola de indignación se levantó en las cuencas mineras. Ante esta situación, los mineros decidieron en su inmensa mayoría que en lo sucesivo, si bien no asistirían al entierro de sus compañeros víctimas de accidentes mortales no trabajarían casi nada en la mina, expresando así de una parte sus sentimientos de duelo y de otra, su repulsa y protesta contra el régimen,

32 Entrevista a Ignacio Peón Fonfría, AFOHSA, serie Movimiento Obrero.

33 MARTÍN ANGULO, Francisco. Los mineros... ;acusan! ¡Las huelgas! Madrid: Sedmay, 1977, p. 87.

34 Carta de la esposa de un minero, 20-IV-64, Correspondencia REI, AHPCE.

35 La canción "La planta 14" del cantautor asturiano Víctor Manuel expresa ese ambiente de odio de clases en el contexto de un accidente minero con una claridad que explica en parte su casi obligada inclusión en el repertorio de sus conciertos a lo largo de décadas. 
que es en definitiva el causante de la muerte de los trabajadores de la mina. ${ }^{36}$

Este pulso, largamente sostenido, se convertirá en los años sesenta en una fuente permanente de conflictividad que acabará por saldarse con la victoria de los mineros, que logran imponer el hábito de parar cuando se producen accidentes mortales. La reglamentación de 1971 acaba reconociendo este derecho bajo condiciones que, en la práctica, siguen siendo desbordadas. La acusada sensibilidad que distingue a los mineros en relación con la muerte por accidente laboral actúa como catalizador de solidaridades sectoriales y comunitarias y propicia una fuente de tensiones y conflictos que entrañan un desafío a la dictadura contra el que de nada sirvieron sanciones y coacciones.

Los paros como expresión de duelo por un compañero muerto en accidente expresan tanto una solidaridad de oficio profundamente arraigada en los mineros como una medida de presión para reivindicar medidas de seguridad. A la larga, esta práctica será trasladada a otros sectores laborales como la siderurgia, si bien, significativamente, esto sucede tan sólo en las factorías con tradición de movimiento obrero y no en la de Avilés, que carece de tales antecedentes. En los años 70, la fábrica de ENSIDESA en Gijón adopta el hábito de parar en caso de accidente mortal, pero la avilesina de la misma empresa no lo hace. La diferencia estriba en que los trabajadores de la primera provienen de las cuencas mineras, desde donde han sido trasladados al entrar en funcionamiento una nueva factoría más moderna. ${ }^{37}$ La misma transmisión se produce en otras empresas metalúrgicas gijonesas hacia las que irradian los códigos firmemente asentados en la minería. EI aprendizaje a través del ejemplo de los mayores y del ambiente social, trasladado por los más jóvenes a otro entorno, queda de manifiesto en el relato de Antón Saavedra acerca de su despido de una subcontrata del astillero Constructora Gijonesa:

\begin{abstract}
Se mató un chaval que era calderero y a mí, que iba con la cultura de accidentes mortales de las cuencas, me chocó que allí por eso no se parara. Yo todavía me acuerdo de cuando mi padre iba a trabajar a las 6 de la mañana y aparecía en casa a les 7 y pico porque alguien se había matado. Yo era un guaje y comía el bocadillo que traía mi padre, tortilla que sabía a mina, y que siempre relaciono con eso, con que se había matado uno y mi padre volvía para casa. Llego a Gijón y la gente trabaja el día del entierro. Y entonces yo y un paisano comunista, Turón, paramos el astillero. Me temblaban las piernas. Al día siguiente me mandaron para casa. $Y$ al siguiente a buscar trabajo.... ${ }^{38}$
\end{abstract}

El testimonio de Saavedra combina nostalgia y recuerdos de infancia con el aprendizaje de los códigos de solidaridad. Su padre, vigilante de mina, aparece también en el testimonio de Anita Sirgo como uno de los primeros que fueron interceptados por los piquetes de mujeres que extendieron la huelga de 1962 en la cuenca del Nalón y que, al encontrárselas, actuó espontáneamente como difusor de la consigna de dar la vuelta y no entrar al trabajo. 


\section{Vínculos comunitarios: las mujeres llevan el peso}

Resulta especialmente destacado el papel que corresponde a las mujeres en el sostenimiento de diversas formas de solidaridad, a veces conscientemente política ${ }^{39}$ (piquetes para extender las huelgas, recogidas de firmas, visitas a autoridades, campañas por la amnistía, el regreso de los desterrados o la readmisión de los despedidos) y otras puramente de apoyo a sus maridos o familiares..$^{40} \mathrm{El} \mathrm{rol}$ de esposas y madres se convierte en un refuerzo considerablemente eficaz: ayuda a ser recibidas, concita simpatías, capta solidaridades vecinales... La presencia de los hijos potencia en ocasiones esa vertiente. Las esposas de presos o deportados ejercen una denuncia sorda de la dictadura con su mera presencia, como bien percibe el Delegado Provincial de Sindicatos en 1962 al sugerir que también ellas sean deportadas. ${ }^{41}$

En situaciones de extrema represión (durante la guerra e inmediata postguerra), presos y huidos focalizan la solidaridad, en tanto que las mujeres articulan redes de ayuda a quienes están recluidos en cárceles y campos de concentración. El primer núcleo organizado de comunistas asturianos responde a la iniciativa de un grupo de mujeres que entablan contacto a partir de su coincidencia en las puertas de la cárcel de Gijón para visitar a sus familiares presos, creando el primer comité provincial tras la derrota. Sus tareas consisten primordialmente en canalizar ayuda a los presos, proporcionar refugio a huidos y actuar de enlace con una red de evasiones que se ocupa de sacar de España a los que corren mayor riesgo en caso de ser capturados. También mujeres y niños desempeñan tareas esenciales en la red de enlaces y apoyos con que cuentan los huidos que sobreviven en los montes e integran la resistencia guerrillera.

Desde muy pronto, la recogida de ayudas para paliar las dificultades económicas de presos y despedidos se convierte en una práctica habitual que hace frente con relativo éxito al acoso policial a que está permanentemente sometida. Su forma más elemental consiste en hacer llegar a las familias productos de primera necesidad (generalmente alimentos, a veces también ropa), si bien en ocasiones puede adoptar formas como la acogida temporal de niños en casa de parientes o vecinos e incluso otros favores como dar clases gratuitas. ${ }^{42}$ Algunos testimonios ilustran la forma sutil pero efectiva en que estas solidaridades se hacen efectivas:

Una me traía un cestín con un kilín de fabes o una botellina de aceite, otra traía un kilo de garbanzos o un kilo de arroz. Y así venían las probes

39 CABRERO BLANCO, Claudia. Mujeres contra el franquismo (Asturias 1937-1952) Vida cotidiana, represión y resistencia. Oviedo: KRK, 2006. ABAD, Irene. En las puertas de prisión. De la solidaridad a la concienciación política de las mujeres de los presos. Barcelona: Icaria, 2012. BABIANO, José (ed.) Del hogar a la huelga. Trabajo, género y movimiento obrero durante el franquismo. Madrid: Catarata/Fundación $1^{\circ}$ de Mayo, 2007.

40 Así se trasluce en algunas entrevistas de militantes que no cuentan con la identificación ideológica de sus esposas pero sí, en cambio, con una colaboración basada en la aceptación resignada de los riesgos en que incurre su marido. Entrevista a Joaquín Fernández Espina (Gijón, 27-IX-1993). En el mismo sentido, Azucena Álvarez acepta dar cobijo en su casa a dirigentes clandestinos porque es el deseo de su marido, militante comunista, aunque el miedo es el sentimiento imperante en ella, tal como expresa en el documental de BANDE, Ramón Lluis. El Paisano. Un retratu colectivu. Robert PC, 2005.

$41 M^{a}$ Luisa Álvarez permanecía con sus cuatro hijos durante horas en el exterior de la comisaría o el cuartel de la Guardia Civil cada vez que su marido era detenido, causando la incomodidad de los mandos policiales, ÁLVAREZ LLORENTE, María Luisa. Tenía que contarlo. Oviedo: Fundación Juan Muñiz Zapico, 2000, p. 69 y 75. Respecto a las esposas de los deportados y la sugerencia de desterrarlas junto a sus maridos, carta de Eliseo Sastre del Blanco, Delegado Provincial de Sindicatos, septiembre 1962, AHP-SGC.

42 La hija de Manuel García Valle recibe clases gratuitas mientras él permanece en prisión: MUÑIZ SÁNCHEZ, Jorge. op. cit., p. 52. 
mujeres y con aquello yo ya tenía para ponerle el cocido a mis hijos. ${ }^{43}$ Nosotros siempre estuvimos dependiendo de los vecinos. Los vecinos, cuando estaba el mi hombre preso... yo tenía las dos crías pequeñas y entonces pues una te traía garbanzos, otra te traía azúcar, había uno que era panadero, traía el pan (... ) Yo era una persona muy conocida en mi pueblo, y muy querida entre los vecinos, hay que decirlo. Por mi casa pasó mucha gente, algunos extranjeros, y (los vecinos) nunca me delataron, ni me denunciaron. Es más, siempre me ayudaron. Una me llevaba pan, otra garbanzos... Y a mis hijas las vestía con la ropa que me daban. ${ }^{44}$

Ya sea como receptoras o donantes, las mujeres protagonizan normalmente estas ayudas que, cuando pertenecen al terreno de las relaciones personales, suelen moverse en el ámbito de los vínculos de amistad, parentesco o vecindad. La ayuda a los presos políticos (alimentos, ropas y otros objetos para ellos valiosos) llega a alcanzar un carácter más amplio cuando grupos de mujeres vinculadas a ellos emprenden campañas de recogida de víveres, generalmente aprovechando la proximidad de fechas como la Navidad. Para evitar sospechas e indirectamente hacer más efectivo el componente de denuncia política, se procura recoger alimentos y se declina recaudar dinero. A las mujeres corresponde también habitualmente la tarea de introducir y sacar informaciones, documentos y propaganda de las cárceles aprovechando sus visitas a los presos.

En situaciones de conflicto laboral, pese a que los huelguistas (mineros y metalúrgicos) son casi exclusivamente hombres, las mujeres desempeñan funciones de vital importancia, tanto en la extensión como en el sostenimiento. Su eficacia descansa en buena medida sobre la apelación a la masculinidad de los trabajadores. Su demostración de valor al desafiar a la represión se convierte por sí sola en una afrenta para quienes muestren cobardía. De ahí la facilidad con la que los piquetes integrados por mujeres consiguen extender una huelga. En las primeras huelgas (1957 y 1958), los mineros tienden a encerrarse en el interior de los pozos, como forma de sentirse a resguardo de la previsible contundencia policial. Entre tanto, las mujeres se concentran en las inmediaciones de las minas y, cuando se produce la salida de los encerrados, los protegen con su presencia. En 1962, la generalización de la huelga en la cuenca del Nalón se debe en gran medida a la formación de piquetes integrados exclusivamente por mujeres. A su vez, la prolongación del conflicto hace que recaben la solidaridad de comerciantes que aceptan suministrar víveres que no han de cobrar hasta que se restablezca la normalidad y se cobren los salarios.

La solidaridad obtenida del pequeño comercio proviene de una simbiosis que guarda estrecha relación con la mutua dependencia. La compra a crédito es una práctica heredada de tiempos en los que los salarios permanecían al borde de la subsistencia y permite al pequeño comercio asegurar la fidelidad de sus clientes, que, a su vez, suelen penalizar cualquier otra actitud por parte de los tenderos. En situaciones de necesidad como las originadas por huelgas de larga duración, los vínculos comunitarios se refuerzan y las situaciones de tensión que viven los directamente afectados se proyectan al conjunto del barrio o la localidad mediante presiones que se sienten legitimadas por una cierta autoridad

43 Testimonio de Rosario Pérez Henares, recogido en el documental Hay una luz en Asturias... También Francisco Prado Alberdi recuerda cómo, de forma anónima, depositaron una cesta de la compra con diversos alimentos en la puerta de su casa mientras se encontraba despedido por su actividad sindical.

44 Testimonio de Anita Sirgo, Serie Disertaciones, AFOHSA. 
moral de quienes sufren. Sobre esta lógica se asientan reacciones como la de las mujeres del poblado minero de Barredos, quienes, en el transcurso de la huelga de 1962 presionan hasta conseguir el cierre de los cines..$^{45}$ La diversión y el negocio resultan hirientes para la sensibilidad de aquellos que sostienen el esfuerzo en condiciones penosas. De ahí que resulte poco clara en la práctica la diferencia entre las acciones directamente encaminadas a mantener la paralización del trabajo y las que extienden el conflicto a su entorno inmediato, favoreciendo un clima de tensión movilizadora basado en la alteración de la normalidad cotidiana. Durante la huelga de 1958 en La Camocha, un piquete centrado en parar el pozo se transforma espontáneamente en una patrulla vecinal que paraliza el barrio. Tras haber soltado las mulas, volcado carruchas con madera y parado el almacén y el lavadero, un grupo de mineros ahuyenta a los esquiroles y se encamina al poblado, donde

nos presentamos en un bar. Increpamos a los parroquianos por estar allí pasando el rato mientras los demás estábamos en huelga, y les advertimos de que no podía ser que la mina estuviera cerrada y el bar abierto. No hubo más que hablar: el propietario echó el cierre y todos a la calle.

A unas cuantas mujeres que presenciaron la escena les pareció muy bien lo de cerrar el bar (...) Cuando nos dimos cuenta, las mujeres de La Camocha se habían unido a nosotros y por las calles del pueblo íbamos cuatro o cinco mineros con veinte o treinta de aquellas mujeres cerrando el resto de los bares, las pocas tiendas e incluso el cine. ${ }^{46}$

Cuando la movilización femenina adquiere formas organizadas y se proyecta sobre los hombres, las mujeres están al mismo tiempo apelando a los roles de género tradicionales y transgrediendo sus códigos, en tanto toman la iniciativa e irrumpen en la escena pública ejerciendo directamente presión sobre los varones. Al mismo tiempo, esta transgresión del rol femenino representa un desafío especial para los represores, que encuentran dificultad para tratar las protestas protagonizadas por mujeres con los mismos métodos que aplican contra los hombres. Una vez dejados atrás los años de la inmediata posguerra, en los que las violaciones, palizas, vejaciones, cortes de pelo y otras humillaciones públicas formaban parte de una experiencia cotidiana de socialización del terror, las denuncias de torturas o malos tratos a mujeres adquieren una particular resonancia y merecen una repulsa más amplia. De algún modo, el carácter habitual - casi rutinario - de las torturas a militantes clandestinos y palizas más o menos indiscriminadas a cualquiera que se vea envuelto en una movilización acaba por convertir en "normal" la violencia represiva ejercida contra los hombres. En los ambientes antifranquistas se da por supuesto que ese es un precio inevitable del compromiso militante, lo cual paradójicamente reduce el impacto emocional de su constatación y denuncia en los casos concretos en que se produce. No faltan incluso quienes entienden que un excesivo énfasis en resaltar la brutalidad de las torturas puede resultar

45 GARCÍA PIÑEIRO, Ramón. “Mujeres en huelga”. In: VEGA GARCÍA, Rubén (coord.), op. cit., 2002, p. 244. Una actitud similar se adopta, en el transcurso de la misma oleada huelguística de la primavera de 1962, en la localidad vasca de Baracaldo, donde la mayoría boicotea el baile del domingo y los pocos que participan son abucheados: AIZPURU, Mikel. Barakaldo, una ciudad industrial. Esplendor, crisis y renovación (1937-2004). Bilbao: Beta III Milenio, 2010, p. 87-88.

46 IZQUIERDO, Jaime Marcelo. Los otros niños de la guerra. Oberón, Madrid, 2004, p. 123. 
contraproducente en tanto que infunde el temor en los círculos de simpatizantes e inhibe la incorporación de nuevos compañeros a las filas clandestinas. ${ }^{47}$

Por el contrario, la denuncia de maltrato ejercido contra mujeres concita siempre una repulsa intensa y por ello genera mayores contradicciones en los agentes de la represión. El más conocido de los documentos de denuncia de torturas referidos a Asturias, el manifiesto suscrito en 1963 por un centenar de intelectuales, sigue siendo recordado hasta el día de hoy por su referencia a los cortes de pelo infligidos a dos mujeres: Constantina Pérez y Anita Sirgo. ${ }^{48}$ Pero incluso antes de que el incidente fuera aireado en ese manifiesto, los propios mandos policiales demostraron ser conscientes del riesgo que entrañaba su conocimiento, de modo que al mismo tiempo que ponían en libertar a varios mineros con el cuerpo magullado y el rostro desfigurado plantearon a las mujeres la exigencia de cubrir su cabeza con un pañuelo si querían retornar a sus casas y, ante la negativa de éstas, optaron por mantenerlas en prisión hasta que el pelo les hubiera crecido y desapareciera la evidencia de que habían sido rapadas. ${ }^{49} \mathrm{La}$ resonancia alcanzada por este episodio ayudaría pocos años más tarde a consolidar una idea muy extendida ( $\mathrm{y}$ obviamente indemostrable) acerca de los malos tratos como origen del cáncer que acabó con la vida de Constantina Pérez. En un sentido similar, Eufrasia Alves atribuye la causa de la minusvalía psíquica con la que nació su hija a un golpe recibido en el vientre en el octavo mes de gestación.

\section{En torno al trabajo: colectas y fondos de solidaridad}

De forma sistemática, la participación en conflictos laborales durante el franquismo era causa de despidos y encarcelamientos que tenían como principal propósito descabezar al movimiento obrero apartando a quienes habían liderado las reivindicaciones del contacto con sus compañeros. También de forma habitual, estas situaciones daban lugar a la recogida de ayudas que trataban de paliar los efectos económicos de la represión, al tiempo que se convertían en una forma tácita de denuncia de la misma.

Cuando las ayudas consisten en cantidades en metálico, requieren cierta organización, puesto que vienen precedidas de colectas entre compañeros de trabajo, vecinos o trabajadores de otras empresas o bien se deben a dinero llegado del extranjero de forma clandestina, en cuyo caso el conducto obligado son partidos y sindicatos, únicas estructuras capaces de canalizar este tipo de solidaridad. Sea cual sea el origen del dinero, su custodia y entrega han de hacerse en medio de cautelas para evitar la incautación por parte de la policía, cuyo acoso ha de ser eludido. De ahí que no sea infrecuente hacer llegar la ayuda mediante sobres introducidos de forma anónima por debajo de la puerta, de modo que ni los propios beneficiados conozcan el origen o la persona que se lo ha hecho llegar. Una esposa de minero relata:

Llevando 35 días de huelga, el lunes, cuando me pongo a limpiar la ropa de mi marido del día anterior, vi caer del bolsillo un sobrecito cerrado. Yo le pregunto a mi marido, que se encontraba a mi lado, qué era. Al decirme él que no sabía nada, y que él no había visto el sobre hasta

47 Este es el punto de vista de Manuel Álvarez Ferrera, durante algunos años dirigente clandestino del PCE (Gijón, 11-X-1994).

48 DÍAZ, Irene. Vanguardia obrera e insurrección firmada. La huelga minera de 1963 y las contradicciones de la dictadura franquista. Gijón: Ateneo Obrero, 2006.

49 Testimonio de Anita Sirgo. 
aquel momento, lo abrimos y contenía 500 pesetas y una pequeña nota que decía: ‘una pequeña ayuda que viene del exterior'. De los ojos de mi marido se desprendieron unas lágrimas, a la vez que decía: ¿Quién habrá sido? Quizá sería cuando estaba mirando una partida de bolos, había mucha gente, pero yo no sentí que me hubieran metido nada..$^{50}$

Al mismo tiempo, esa necesidad de eludir la vigilancia confiere un mayor significado político a lo que para muchos no son sino actos elementales de solidaridad:

La policía no deja del día de paga acercarse a las impresas a los despedidos, porque son conocidos y la jente se ba marchando unos por cada camino. $Y$ después hay que recurrir a recaudar en las esplotaciones o en el bar, pero eso trae buenas multas a todos los que sean descubiertos por la policía. En el pozo Nicolasa fueron multados cinco obreros con mil pesetas cada uno por recaudar el dinero. Dicen que fue orden gubernativa el multarlos. ${ }^{51}$

En el caso de trabajadores despedidos, las colectas son una respuesta habitual y tiene lugar generalmente en los días de paga. Suelen ser iniciativa de compañeros de trabajo o de militantes, pero no faltan las ocasiones en que, para otorgar mayor eficacia y revestir el acto de un componente de denuncia, son los propios despedidos los que acuden a la salida del trabajo los días de paga o, si se encuentran desterrados, son sus mujeres las que se presentan, incrementando la presión moral no sólo sobre la generosidad de los trabajadores sino también sobre las empresas a las que se exige la readmisión o sobre las autoridades que han de levantar las medidas de destierro.

Las colectas encierran propósitos no sólo recaudatorios sino también de concienciación. Pueden servir a los militantes clandestinos tanto para pulsar el apoyo con que cuentan como para reclutar a quienes se muestran más dispuestos. Así lo recuerda Faustino Sánchez, quien en 1958 se responsabiliza de una caja de solidaridad que es organizada de inmediato tras la "caída" de militantes comunistas de la cuenca del Nalón. ${ }^{22}$ La aportación económica constituye a veces el primer paso para la aproximación a mayores niveles de compromiso y, por tanto, de riesgo. Además de compañeros que han sido despedidos, los presos políticos son los principales destinatarios de esta solidaridad cuya vertiente política resulta manifiesta. El comunista gijonés Gerardo Lorda relata cómo en la factoría siderúrgica de Fábrica de Moreda y en la mina de La Camocha se realiza a fines de 1950 una rifa cuya recaudación es destinada a los presos de los penales de Burgos y El Dueso. La tarea no corre a cargo exclusivo de los militantes clandestinos, que son en realidad muy pocos, y encuentra una acogida favorable entre la mayor parte de los trabajadores. Nuevamente en 1952, cuando el propio Lorda es encarcelado, recibe todos los meses el fruto de una colecta realizada entre sus compañeros. ${ }^{53} \mathrm{~A}$ su vez, a mediados de los años cincuenta, en la cuenca minera del Nalón, Manuel García Valle inicia su compromiso antes de integrarse en las filas del Partido Comunista recaudando dinero para los presos entre los mineros del pozo en que trabaja. ${ }^{54}$

50 Correspondencia REI, 18-XI-63, AHPCE.

51 Transcripción literal de una carta remitida a la emisora Radio España Independiente. Correspondencia REI, 18-V-1965, AHPCE.

52 Entrevista a Faustino Sánchez, facilitada por Ramón García Piñeiro.

53 Entrevista a Gerardo Lorda Solares (Trubia-Gijón, 24-XII-1994).

54 MUÑIZ SÁNCHEZ, Jorge. op. cit., p. 67. 
A partir de los años sesenta, las situaciones de necesidad ocasionadas por huelgas que se tornan más frecuentes y llegan a prolongarse durante meses dan lugar a iniciativas que nacen del seno de organizaciones confesionales o se cobijan bajo el amparo de la Iglesia. Algunos curas realizan colectas, organizan comedores para hijos de huelguistas o dan facilidades para que militantes del apostolado obrero realicen actividades de carácter solidario. Estas respuestas se hacen extensivas al entorno social no directamente ligado a la minería, acogiendo a hijos de huelguistas u organizando comedores para ellos. La ovetense Carmen Bobes recuerda cómo siendo profesora en el Instituto de Mieres se organiza durante la huelga de 1962 un comedor "en el que dábamos una sopa caliente muy barata para acompañar al bocadillo que los chavales traían de casa”. No fue una iniciativa aislada sino que "se hizo igual en el de Aller". ${ }^{55}$ Bajo formas diversas, los conflictos prolongados concitan apoyos que ayudan a sostener la resistencia:

Obreros de otras industrias ayudan a las familias mineras, se hacen cargo del sostenimiento de los hijos de los huelguistas. Otros, comparten con los mineros, en algunos casos se la ceden, la modesta cosecha de patatas que obtienen en los trocitos de tierra que cultivan. 'Para que puedan aguantar más', hay gentes que les procuran algún trabajo donde puedan ganar unas pesetas arriesgándose a la multa, pues dar trabajo a los mineros en huelga es cosa que las autoridades franquistas prohíben terminantemente. Hay tenderos que facilitan comestibles a las familias de los huelguistas, 'para que los paguen cuando puedan', mostrando así su simpatía por la valerosa acción que sostienen. ${ }^{56}$

En el mismo sentido se expresa un recuerdo de juventud de una persona cuyo entorno familiar y de amistades se caracteriza por la escasa politización, sin ser por ello ajenos al clima general que se respira en las cuencas mineras durante la huelga de la primavera de 1962:

\begin{abstract}
De forma espontánea. Nadie de los que yo conocía, recibió órdenes de que buscáramos familias con hijos que lo estuvieran pasando mal, que pasaran hambre, y, sin embargo, lo hicimos. Íbamos por Sotrondio y El Serrallo y alguien nos decía: 'en casa de fulano son seis y seguro que pasen fame”. Y llevábamos los guajes a nuestra casa a comer. Nos los repartíamos diariamente. ${ }^{57}$
\end{abstract}

Las prohibiciones y el hostigamiento que ejerce la autoridad gubernativa no impiden que las expresiones de solidaridad con huelguistas y represaliados sean vistas como una respuesta "natural" y cuenten con la aprobación moral de una amplia mayoría, cualquiera que sea su adscripción ideológica. El socialista Avelino Pérez da cuenta de la buena respuesta que encuentran las peticiones de ayuda, en este caso para un viaje a visitar a presos políticos:

Porque no teníamos un céntimo y las mujeres querían ir a Carabanchel a ver a los detenidos y teníamos allí a 16. (...) Y nosotros recogimos en aquel momento solamente en Sama de Langreo setenta y seis mil pesetas para mandar a las mujeres a Madrid. Hasta un falangista

55 La Nueva España, 1-VIII-2011.

56 Mundo Obrero, $\mathrm{n}^{\circ} 15,2^{\mathrm{a}}$ quincena septiembre 1963.

57 César González Antuña: “Un recuerdo que se mantiene vivo”, La Nueva España, 7 de mayo de 2012. 
que se llamaba Tito Escudero nos dio mil duros, cinco mil pesetas. Un republicano, un sastre que había sido republicano, Castaño, ocho mil pesetas. Era mucho dinero entonces. Mucho dinero..$^{8}$

También en medios ligados a la Iglesia logran imponerse estas prácticas:

La JOC de La Camocha, desde los primeros momentos de la huelga afrontó los problemas existentes, empleando los fondos que tenía destinados para una peregrinación a Lourdes en socorrer a las familias necesitadas, distribuyendo un valor de 3.000 pesetas en paquetes de alimentos, incluso leche para niños. En la actualidad el secretariado parroquial ayuda con las existencias de Cáritas a nueve familias de la localidad, mujeres de detenidos y enfermos. ${ }^{59}$

Pero incluso las organizaciones confesionales tienen problemas a la hora de recoger y distribuir ayudas:

Para socorrer a varias familias necesitadas, especialmente de los detenidos con motivos de las huelgas, el militante hoacista José Rey Arias realizó una colecta entre sus compañeros de trabajo el día 10 de mayo. Su importe fue íntegramente entregado a las indicadas familias. El día 10 de junio se repitió la misma colecta con el mismo fin y con idénticos resultados económicos. Con este motivo José Rey Arias fue detenido y encarcelado con condena de 10 días impuesta por el Gobernador Civil. Gracias a las gestiones del Consiliario Diocesano con el señor Gobernador no se cumplió la condena y fue puesto en libertad a los seis días. A la vista de los acontecimientos la JOC de La Camocha, para ayudar a las citadas familias, ha puesto en marcha un sistema de socios protectores de la organización. ${ }^{60}$

A su vez, las organizaciones clandestinas, que siempre han encontrado en la solidaridad con presos y represaliados una de sus razones de ser y desde un primer momento han procurado organizar la distribución equitativa de los recursos en el interior de las prisiones (mediante la puesta en común de lo recibido a través de comunas) y han enviado fondos recaudados en el exilio, tratan de colaborar en el sostenimiento de las huelgas cuando éstas se prolongan y de asegurar la cobertura a todos los presos políticos y despedidos a causa de los conflictos laborales. Esta voluntad, dificultada por las desconfianzas y rivalidades que atraviesan a las fuerzas antifranquistas, se materializa con motivo de los despidos masivos a que da lugar la huelga de 1964 y alcanza una estructuración estable y (a pesar de las trabas policiales) con publicidad a fines de esta década, desembocando en 1972 en un fondo solidario permanente, unitario y con notable capacidad de recaudación que no deja de funcionar ni de rendir puntualmente cuentas hasta que la amnistía y la legalización de los sindicatos hagan innecesaria su existencia.

La solidaridad con los represaliados constituye de este modo un continuum que se manifiesta de forma permanente a lo largo de toda la dictadura, encuentra

58 Testimonio de Avelino Pérez, serie Disertaciones, AFOHSA.

59 Conflictos laborales y hechos de vida obrera. Enviado el 16 de julio de 1958. Gijón. J.M.F, Archivo Comisión Nacional de la JOC.

60 Ibídem. A causa de su reincidencia en estas actividades, José Rey será finalmente expulsado de España y permanecerá exiliado en Bélgica. Entrevista a José Rey Arias (Gijón, 23-XI-1994). 
expresiones tanto formales como informales y apela a sentimientos ampliamente compartidos en los medios obreros que sirven de entronque natural entre los militantes organizados y sucesivos círculos concéntricos en los que se desenvuelven y de los cuales reciben aliento y ayuda. Es también uno de los escasos frentes en los que, no sin dificultades, resulta posible una acción unitaria por parte de organizaciones clandestinas entre las que impera la mutua desconfianza o relaciones sectarias, así como con formaciones legales como las del apostolado obrero.

\section{Inclusión y exclusión: liderazgos y sanciones}

Más allá de la pertenencia a alguna organización, el prestigio y la autoridad moral son los principales ingredientes sobre los que se asienta la actuación de quienes encabezan las protestas. Ser un buen trabajador incrementa las posibilidades de llevar a los compañeros a la huelga. Ser valiente e íntegro facilita la actuación como portavoz o la pertenencia a una comisión. La credibilidad es fruto de una combinación de múltiples ingredientes: la destreza profesional, una vida familiar y social ordenada, haber resistido coacciones o torturas... incluso el respeto que merecen padres y abuelos, como si de algún modo las virtudes personales fuesen heredadas.

La conducta de los militantes antifranquistas está sometida a estrictos códigos que remiten directamente a la cultura obrera. Su adecuación a estos códigos determina en gran medida sus posibilidades de liderazgo en el seno del movimiento obrero. En ausencia de procedimientos formales de elección y cauces de representación aceptados, es el ascendiente basado en la trayectoria personal y el comportamiento tanto público como privado el que permite encabezar reivindicaciones, formar parte de comisiones o tener la capacidad para llevar a toda una plantilla a paralizar el trabajo.

En contrapartida al temor imperante en la mayoría, quienes se muestran capaces de resistir las torturas en interrogatorios policiales adquieren una aureola de prestigio que contribuye a reforzar el ascendiente que ejercen sobre compañeros y vecinos. No pocos de los liderazgos del movimiento obrero se deben en parte al comportamiento observado durante las torturas. Haber permanecido firme, sin arrastrar a nadie, cortando la cadena de las detenciones, constituye un timbre de gloria para los militantes clandestinos. El respeto y admiración de sus camaradas se hace a menudo extensivo al ámbito laboral y les permite desempeñar un papel destacado encabezando las reivindicaciones. Juega a su favor el hecho de que la condición de portavoz o la pertenencia a una comisión de trabajadores constituyen en sí mismas una selección natural que descarta a los más temerosos y descansa sistemáticamente sobre los que logran vencer el miedo. El testimonio del comunista Faustino Sánchez resulta expresivo al respecto:

A la hora de dar la cara con el capataz, no aparecía nadie, salvo dos o tres. Según salías había que subir veinte escalones y se daba el caso curioso que nos juntábamos unos cuantos para hacer la reclamación, pero, a medida que nos acercábamos a la oficina, iba menguando la comitiva: uno porque tenía que atar el cordón de la alpargata, otro porque se distraía... y ante el capataz quedábamos uno o dos a lo sumo. En estas movilizaciones ya se estaba formando una selección: el que daba la cara sobresalía y así se iba adquiriendo el aprecio de los compañeros. Así funcionaba la escuela donde se formaban los líderes: ibas ascendiendo en un escalafón invisible. 
Sin proponértelo siquiera, te ascendían a general y cuanto más arriba más responsabilidades y más palos llevabas después cuando te enganchaba la policía. El Partido luego seleccionaba aún más: te cogía la policía, te machacaban en la comisaría, no 'cantabas' a nadie y te ganabas la confianza del Partido. Ya te consideraban un dirigente. De la rebeldía inconsciente a la dirección del Partido y casi sin enterarse. ${ }^{61}$

A su vez, los dirigentes clandestinos pueden llegar a estar rodeados de una aureola de admiración que los convierte en figuras cuasi legendarias. Las duras condiciones en que se desenvuelve su actividad, el riesgo que corren y la obsesión de la policía por arrancar informaciones sobre su paradero en los interrogatorios refuerzan su autoridad. Ante la nueva generación que se incorpora a la militancia desde fines de los 50 y toma el relevo en los 60 se erigen en un referente moral:

Era el valor que tenía esta gente que en aquellos años, y eran los que daban autoridad a los que empezábamos, porque sin esa autoridad era difícil tener valor pa tirar adelante. O sea el ejemplo de la gente que estaba al frente de las luchas era lo que a ti te daba moral. Si no, era imposible... Y después, claro, ver personas como Horacio, como Ángel León y como Mario Huerta. Gente así que estaban siempre en la brecha, que tenían un comportamiento que tú decías: esta gente lo está dando todo, por ahí escondidos, viviendo de una manera mala. ${ }^{62}$

Por su parte, la propaganda franquista incidirá de forma sistemática en el descrédito de los opositores apelando a los mismos códigos y tratando de presentar a los militantes clandestinos como indignos de la confianza de sus compañeros. Unos y otros remiten en realidad a la misma lógica, profundamente instalada en la conciencia de la mayoría. Desde las filas de la dictadura, ya sea de forma genérica a través de los medios de comunicación que hablan de "agentes pagados con el oro de Moscú" o de acusaciones personalizadas a cargo de los aparatos sindicales o policiales, se busca presentar a los militantes antifranquistas como corruptos que reciben dinero por su labor o bien se apropian del que otros entregan de buena fe. Esta estrategia de descrédito a través de la insidia y la calumnia no se limita a la propagación de rumores sino que puede encontrar una expresión escrita mediante octavillas de factura policial falsamente atribuidas a grupos de oposición. Una línea de actuación que sigue directrices bien calculadas para dar lugar a

una propaganda adecuada e inteligente, que debiera ser distinta para cada centro de trabajo, en la que se citarán nombres y circunstancias que llevarán indefectiblemente al desprestigio a quiénes pretenden el ascendiente vinculativo que el PC les tiene señalado como objetivo indispensable para la movilización, la protesta, las reuniones y, por último, la huelga. Esta propaganda requiere absoluta discreción y sobre todo enmascaramiento del campo de procedencia, existiendo más que sobradas siglas de organizaciones de la oposición fraccionadas que pudieran servir, sin posibilidad de descubrirse para dar un marchamo de realismo al plan propugnado. ${ }^{63}$

61 Entrevista facilitada por Benigno Delmiro Coto.

62 Entrevista a José Celestino González "Tino el del Alto" (Gijón, 25-I-1996). Los nombres que menciona son dirigentes clandestinos del PCE en Asturias.

63 "Nota de la Brigada de Investigación Social sobre las Comisiones Obreras", 23-l-1967, AHA, Sección Gobierno Civil - Secretaría Particular - Oficios y Circulares, caja 22627. 
Se trata de un tipo de ataque particularmente eficaz que los afectados se ven en la necesidad de contrarrestar de inmediato. De este modo se explica la puntual y detallada información que acaban ofreciendo los fondos de solidaridad creados en los años sesenta y setenta acerca de las cantidades recaudadas, su procedencia y su destino. Las acusaciones han pervivido, de todas formas, hasta el presente y es posible encontrarlas, en formulaciones muy similares a las originales, en testimonios orales. Las sombras de sospecha sobre la integridad de los militantes clandestinos encierran un potencial demoledor. Preservar una imagen de integridad resulta para ellos una cuestión vital que requiere desmentir las acusaciones insidiosas lanzadas por la policía y los partidarios de la dictadura. Una vez más, las emisiones de radio de los comunistas sirven para la contrainformación:

Este artículo que os mando, espero lo corrijáis algo, pero creo que es importante publicarlo para terminar con la especulación e intriga de Pérez y Ramos, que ya que no pueden desprestigiarnos políticamente, intentan hacerlo con difamaciones y calumnias, valiéndose para ello de algunos indeseables. Claro que la gran mayoría no les hacen caso. Me parece conocéis algo a este respecto, pues se dedican a divulgar que si Fulano marchó con 2.000.000 de pesetas que venían para los huelguistas, que si Mengano pagó tanto para sacar a su esposa, si Citano le costó 100.000 pesetas por operar a su esposa, si tal o cual compraron pisos en Gijón, todo con el dinero que viene para los huelguistas. ${ }^{64}$ [Correspondencia REI, 13-V-64]

Las acusaciones lanzadas por la propaganda franquista no carecen, sin embargo, de eficacia. Su mayor refuerzo consiste en que proporcionan una coartada moral a quienes se muestran hostiles a las movilizaciones y sufren, por ello, el rechazo de un entorno que alienta códigos solidarios que penalizan las actitudes individualistas y, más aún, el comportamiento de los esquiroles. Adjudicar conductas deshonestas a los que lideran las luchas ofrece argumentos para romper ese cerco y construir una autojustificación:

\begin{abstract}
Yo estuve en la huelga del 62 y a mí nadie me dio nada de dinero. Y sé de gente que cobró muchu dinero, que lu mandaben de los partidos de Francia y Bélgica y too eso por ahí. El Partido Comunista mandaba dinero pa los mineros, pero quedábanse cuatro con ello y los otros cuatro teníamos que tar pasando fame.

Yo, de comentarios que tengo oídos (...) que ganaron mucho dinero mucha gente a costa de las huelgas. Gente que lo revolvía (...) y de aquí marchó mucha gente, de la barriada, después de pasar las huelgas, marchó bastante gente de aquí, asturianos y de todo. Yo aquello no lo entendía, pero sé que gente se hizo con mucho dinero a costa de las huelgas. Mandaban dinero del extranjero y la gente en vez de repartirlo con los mineros, pues la mayoría se quedaba con el dinero en vez de repartirlo. ${ }^{65}$
\end{abstract}

Estas versiones, recogidas en testimonios orales recientes que acreditan su persistencia, son reveladoras de la incomodidad de una parte de la población con los

64 Correspondencia REI, 13-V-64, AHPCE. Los nombres que cita corresponden a policías a cargo de la represión política.

65 Testimonios recogidos en RAMOS BARRERA, Angélica. Migraciones interiores y mano de obra minera en Asturias (1939-1959). Memoria de Licenciatura leída en la Universidad de Oviedo el 30 de septiembre de 2011. 
hábitos y los códigos imperantes entre los mineros, que generan una presión ambiental a la que no pueden sustraerse y a la que se ven sometidos de una forma resignada pero pasiva y hostil. En coyunturas de auge de la conflictividad como las huelgas de la primera mitad de los sesenta, un número significativo opta por emigrar para eludir las tensiones. Otros parecen proyectar su incomodidad contra los organizadores de las huelgas, de tal modo que incluso cuando constatan la represión, adjudican la culpa a quienes fomentaban los conflictos y no a quienes los reprimían. La frecuencia de las huelgas, la fuerte presión a la que se veían sometidos los esquiroles, el desacuerdo ideológico con quienes se considera dirigentes u organizadores, el dilema moral a que se veían impelidos y ante el que normalmente habían de ceder, su falta de valor para actuar de acuerdo con sus convicciones, la incómoda comparación entre su conducta y el compromiso y el riesgo asumido por otros... se combinan como ingredientes que en no pocas ocasiones dan lugar a una reacción de inquina hacia quienes lideraban la lucha. A menudo, en estos relatos la represión no aparece o bien se convierte en un argumento en contra de las movilizaciones, al involucrar en problemas y hacer correr riesgos a quienes no querían tomar parte. Las torturas, despidos, destierros y cárceles quedan en el olvido porque supondrían un desmentido del supuesto enriquecimiento de los militantes. Denigrarlos y cuestionar su honestidad se convierte en un argumento que justifica la propia pasividad o cobardía y que convierte a quienes los secundaban en "tontos útiles" incapaces de ver que estaban siendo engañados:

Casi todo lo que cuentan de la huelga del 62 fue inventado, inventado para ponerse galones cuatro cantamañanas. Vivíase mal y cuatro cabecillas engañaron a la gente diciéndoles que con les huelgues iben a conseguir esto y lo otro. Es más, los cabecillas de la huelga del 62 recibían mucho dinero del Socorro Rojo. Todo era político. ${ }^{66}$

En el momento en que se producen las acusaciones, los militantes antifranquistas las sufren en carne propia, puesto que afectan tanto a su prestigio (el principal de los recursos simbólicos con que cuentan para sostener la lucha) como a su sostenimiento y el de sus familias, al afectar a la recaudación de las ayudas que reciben. Por ello se ven en la necesidad de salir al paso. En 1964, los despedidos de las huelgas mineras, numerosos y organizados en una comisión, hacen pública una carta fechada significativamente en el día de Navidad:

Compañeros:

Seríamos desleales a vuestro esfuerzo si, al cabo de seis meses que llevamos despedidos de nuestros puestos de trabajo, no nos dirigiéramos a vosotros agradeciéndoos vuestra solidaridad.

Durante todo este tiempo no ha faltado el pan a nuestras familias, gracias a vuestra generosidad. En nuestro propio nombre y en el de nuestra familia, gracias de todo corazón.

Pero no es esto sólo lo que os debemos. Nos habéis asistido como hermanos en nuestras hasta ahora infructuosas gestiones en defensa de nuestro derecho al trabajo. Habéis seguido con simpatía y preocupación la defensa de un indiscutible derecho de todo trabajador a vivir de su propio esfuerzo. Habéis comprendido la injusticia que supone nuestro despido arbitrario por empresas donde hemos dejado el fruto de muchos años de vida laboral; y algunos de nosotros nuestra propia salud.

A la vez, salimos al paso para aclarar comentarios que han circulado

66 GARCÍA GARCÍA, José Luis. "La huelga de 1962 en la minería asturiana: experiencia y discursos”. In: VEGA, Rubén (coord.) op. cit., p. 331. 
sobre el paradero de vuestra ayuda. Puedes estar seguro de que llega a nosotros.

Es necesario no hacer caso de quienes intentan sembrar discordia y confusionismo de una manera interesada para desprestigiar nuestra situación de discriminatorio despido. Te decimos esto, porque nuestro despido, como bien sabes, se ha debido no a una postura personal, sino a la participación en un hecho colectivo con el que hemos intentado llamar la atención sobre el gravísimo problema laboral que a todos nos afecta. Ignoramos hasta cuándo puede prolongarse aún nuestro despido. Mientras nos sea posible seguiremos firmes exigiendo nuestra vuelta al trabajo.

La situación es dolorosa, pero nos será más fácil sobrellevarla sabiendo que estáis generosamente a nuestro lado.

Aprovechamos para desearos Felices Pascuas y Año Nuevo.

¡La paz es obra de la justicia!

Asturias, 25 de diciembre de $1964 .{ }^{67}$

Uno de los miembros de esa comisión de despedidos recuerda la vivencia años más tarde. El paso del tiempo fue provocando un desgaste que acabó deteriorando la imagen de quienes seguían recibiendo ayudas y cualquier detalle podía volverse en su contra:

la comisión de despedidos, cuatrocientas, trescientas personas por ahí, viviendo por ahí, eso a la larga llegaba a desgastar. Porque la campaña de desprestigio era terrible. Porque si te veían por ahí tomando unos vinos, si te veían por ahí... Era campaña de desprestigio. Que si te mandaban dinero... aquella fábula del dinero... Mucho, mucho. ${ }^{68}$

La eficacia de las campañas de desprestigio descansa, en última instancia, sobre la existencia de valores compartidos por todos que proporcionan el sustrato en el que prenden las sospechas. Quienes difaman o acusan a los militantes clandestinos lo hacen apoyándose en la misma noción de las cualidades que resultan reprobables conforme a un estricto código de conducta inscrito en la cultura obrera de varias generaciones y favorecido por pautas de estricto control social. En un contexto en que los niveles de vida ofrecían muy escaso margen, cualquier signo de prosperidad, real o aparente, se convierte en sospechoso. Una anécdota que pudo llegar a saldarse con un desenlace trágico permite ilustrar esto. El militante comunista Faustino Sánchez acudía a sus citas clandestinas en una moto conducida por Alfonso Braña cuya calidad despierta el recelo de los camaradas hasta el punto de llegar a la conclusión de que se trata de un confidente o un policía. Y, para evitar que un infiltrado vuelva a dar al traste con la organización enviando a sus miembros a la cárcel, se plantean darle muerte, propósito para el cual llegan a adquirir una navaja. El equívoco se resuelve en el momento crítico en que el "sospechoso" se enfrenta a la acusación, al comprobar que sus manos callosas del trabajo en la mina y la deformación de un dedo propia del oficio de picador le acreditan como uno de los suyos, alguien que "tenía les manes igual que nosotros de trabayar y picar carbón". ${ }^{69}$

Recebido em: 04/08/2014

Aprovado em: 04/08/2014

67 Reproducida en El Socialista, $n^{\circ} 160,14-1-65$.

68 Entrevista a José Celestino González "Tino el del Alto" (Gijón, 25-I-1996).

69 DELMIRO COTO, Benigno. "Perfiles de los comunistas en la Güeria de Carrocera (años 60-70)". In: VVAA, La Güeria. Memoria de un valle, Oviedo: Trabe, 2006, p. 152-155. 